\title{
THE ANALYSIS OF PRICE AND TRADING VOLUME OF STOCKS IN THE INFRASTRUCTURE SECTOR LISTED ON IDX BEFORE AND AFTER THE PRESIDENTIAL ELECTION 2019
}

\author{
Suri Rahma Fahira ${ }^{1}$, Islahuddin ${ }^{* 2}$ \\ 1,2 Program Studi Akuntansi Fakultas Ekonomi Universitas Syiah Kuala \\ e-mail: surirahmafahira97@gmail.com¹, islahuddin@ unsyiah.ac.id ${ }^{* 2}$ \\ * Corresponding Author
}

\begin{abstract}
The purpose of this research is to analyze the market reaction to the presidential election year 2019 indicated by the average price and trading volume of stocks in the infrastructure sector listed on the Indonesia Stock Exchange before and after the Presidential Election. This research used t-test model. It was found that there was no reaction in stock price, both between sectors and within infrastructure sector. While in the volume of trading, there was reaction between sectors, but there was no reaction within infrastructure sector. So, there is market reaction in Indonesia capital market during the event, but the reaction may not be affected by political event. In other words, Indonesian capital market (in this case IDX) did not react to the presidential election
\end{abstract}

Keywords: stock price, trading volume, event study,presidential election year 2019

\section{Introduction}

Political conditions are one of the components in the external environment or non-economic factors that affect stock price volatility. Although political conditions do not have a direct relationship with the dynamics of capital in the capital market, political issues still play an important role in influencing stock prices. Political events such as government shifts, political unrest, new cabinet announcements, and other political problems will affect the volatility of stock prices and trading volume on the capital market because political events are related to the country's economic stability (Nurhaeni, 2009).

The Indonesian General Election, which was held on April $17^{\text {th }}, 2019$, is a very important political event by electing the president and vice president for the next five years. The best choice does not come out easily. Each presidential candidate had tried to promote themselves with vision, missions, and programs which represent the future policies that will affect the country in all aspects, including economics situation.

Infrastructure development program is considered as a superior program of the on-going government. Based on data from the Ministry of
Finance, state budget allocation in the infrastructure sector has increased significant from 2014 to 2019.

The allocation was IDR154.7 trillion in 2014, increased to IDR256.1 trillion in 2015, IDR269.1 trillion in 2016, IDR388.3 trillion in 2017, IDR410.7 trillion in 2018, and IDR415.0 trillion in 2019 (Kementerian Keuangan Republik Indonesia, 2018).

In the implementation of infrastructure development, the government usually cooperates with government- owned and private-owned companies. Collaboration with companies that have labelled -Tbkll or companies listed on the capital market certainly invites market reaction. The market will react because the higher value of cooperation will provide greater profits for the company. It leads an increase of the value of dividends that will be received by shareholders. The more investors enlisted, the more trading volume increased, and as the result, the stock price of the company will increase. In other words, government policy influences price and trading volume of stocks.

There were several studies on market reactions on an event. Research conducted in the 2014 
presidential election in different objects showed no market reaction occurred. This was indicated by differences in abnormal return and trading volume activities before and after the presidential election. Chandra (2015), Sihotang \& Mekel (2015), and P \& Sari (2015), stated that there were no significant difference on the event. A study conducted by Imelda \& Aggraeni (2016) summarized that there were significant differences in abnormal returns and trading volumes of activities before and after three presidential elections (2004, 2009 and 2014). Other study by Putra \& Putri (2018) found that there was a difference in abnormal returns and average trading volume before and after the announcement of Donald Trump's winning victory.

There are two presidential candidates who took part in the 2019 Indonesian presidential election. The ongoing government is one of the candidates in the presidential election and still prefer to continue his work programs. That is why the infrstructure sector will still be the main focus of their campaign. Depend on political environment and public perception, there is still a possibility whether ongoing president will win or loss, replace by a new president with a new program. So that the price and volume of stock trading in the infrastructure sector is uncertain, it could be that the infrastructure sector stocks increase, but it is also still possible to decrease.

However, the fluctuations that occurred recently are still uncertain whether they are occured due to the effects of the political event or not. All of other sectors also need to be investigated as a comparative figure to ensure the market reaction that occurs in the infrastructure sector is because of the political effect. This study is carried out to analyze the political event capability to affect market reactions. Hence, the author is eager to conduct a study to see the market reaction to the infrastructure sector before and after the 2019 presidential election, specifically in the price and trading volume of stock in infrastructure sector, which is entitled IThe Analysis of Price and Trading Volume of Stocks in the Infrastructure Sector Listed on IDX Before and After the Presidential Election 2019\|. In the next section, literature review, research methodology, research results will be discussed.

\section{Literature Review and Hypotheses Stock market}

Selling and buying of stocks create an interaction in the stock market. The interaction increase and decrease the value of the stock, a positive value of the stock indicate a better stock market. The stock market is the leading indicator of a country's economic strength. It provides an estimate of future economic actions. History shows that it has always been a good predictor of the upcoming dejection of the economy. Many studies have demonstrated a strong link between stock market returns and economic activity (Fisher \& Merton, 1984, Barro, 1990, Fama, 1990).

The relationship between stock prices and real economic activity is circular. On the one hand, stock prices depend on a company's performance and its growth prospects so that to the degree that a company's performance improves and the rate of return increases, stock prices rise in turn. Generally, there are three main channels whereby stock prices can affect real economic activity: i) the wealth effect: under the life cycle/permanent income, higher stock prices and increased wealth in stocks lead investors to increase their consumption. This increase in consumption will be more significant in countries where the stock ownership base is large; ii) cost of capital: with stock prices increasing, the cost of the new capital related to existing capital decreases, more companies go public and raise funds for investment through public offerings. In addition, a good performance on the stock market might attract foreign capital, which would allow interest rates to go down (ceteris paribus); and iii) the confidence effect or expectation effect: a highly performing stock market might improve overall expectations, which might induce economic growth through more investment as part of a positive feedback effect. Moreover, stock prices signal faster growth of companies and as a result, possible growth of future real individuals' income might also induce more consumption (Morck et al, 1990). Although these factors/channels are hard to quantify, it is important to accurately assess the strength of the link between stock markets and real economic activity. 


\section{Inf rastructure Sector}

The stocks of the infrastructure sector are included in the tertiary sector (non-manufacturing) or often identified as sector number 7. This sector is also known as infrastructure, utility, and transportation sector. The stock is classified into five subsectors: Energies; Highways, Ports, and Airports; Telecommunications; Transportations; and NonBuilding Constructions. The number of companies stocks that include infrastructure, utility, and transportation sector is 55 companies.

\section{Political Uncertainty}

Political uncertainty describes an unmeasured, subjective doubt about a political environment (Rummel and Heenan, 1978). In other words, every element which in the political business environment raises -doubtll (regulatory measures taken by States, or events triggered by various social groups: terrorism, strikes, revolutions, presidential electionwhich may affect the activity of an enterprise, etc.). The relationship between political uncertainty and economic growth has been a keen area of research in past years and a survey of the extant literature shows that the empirical examinations have been active. In some studies, political uncertainty enters the empirical model set-up as a constraint that is expected to adversely impact on optimal investments and economic growth policies; other studies examine the reversed causal relationship between political uncertainty and economic growth as it is expected that weak economic prospects can induce political uncertainty (Schneider and Frey, 1985; Vega-Gordillo and Alvarez-Arce, 2003). The political experience in recent years has reignited interest on the widely accepted relationship between political uncertainty and economic growth with the focus now shifted to understanding financial markets and related channels through which political uncertainty is transmitted into the real economy (Kelly et al., 2014). Understanding these channels of transmission should aid policymakers to design appropriate frameworks, institutions and policy interventions to help mitigate the cost associated with political uncertainty.

\section{Political Marketing}

Political marketing is a science concept that combines marketing and politics. According to the American Marketing Association (2014) in Subagio (2016), marketing is an activity, a set of institutions, and the process of creating, communicating, sending and exchanging offers that have good value for customers, clients, partners, and society in general. Whereas from a political point of view, Gabriel A. Almond defines politics as an activity related to the control of public decision-making in certain societies in certain regions, where this control is supported through instruments that are authoritative and coercive. That is, to produce a public decision requires power. The power gained is a belief of the community. So, political marketing can be defined as an activity to offer the community to obtain power.

Political marketing does not determine the victory of a political party or presidential candidate. Political marketing is only a method and tool for political parties or presidential candidates to approach the public. The systematization of the approach taken by the candidates needs to be done considering there are always limited resources that each candidate has

\section{Indonesia Presidential Election Year 2019}

The election is the process of selecting a person to fill certain political positions. The positions are varied, started from presidents, legislators at various levels of government, or regional head. The election in Indonesia is originally intended to select the members of representative institutions, such as parliament (DPR), provincial parliament, and Regency/city parliament. After the fourth amendment of the 1945 constitution in 2002, the presidential election which was originally performed by the People's Consultative Assembly was agreed to be voted directly by the people. That means people choose their president directly. The direct Presidential Election was held for the first time in 2004.

The 2019 presidential election aims to choose state leaders, presidents and vice presidents, for the 2019-2024 period. Since the inauguration on September 20, 2018, there have been two presidential and vice-presidential candidates who will be elected in the 2019 presidential election. The two pairs of president-vice presidents are Joko Widodo-Ma'ruf 
Amin and Prabowo Subianto-Sandiaga Uno. Both candidates have the potential to be elected in the 2019 presidential election. The survey results according to LSI Denny JA since mid-August 2018 to February 2019 show that the pair Joko WidodoMa'ruf Amin still outperformed with an estimate votes of more than $50 \%$. However, the results of the survey are still the results of the pre-election survey and even part of the overall pre-election activities. All possibilities can occur. The presidential election was held on April 17 $7^{\text {th }}, 2019$.

\section{Theoretical Framework}

Based on the conclusion and the results from previous studies, as well as according to the research objectives mentioned earlier, the theoretical framework is :

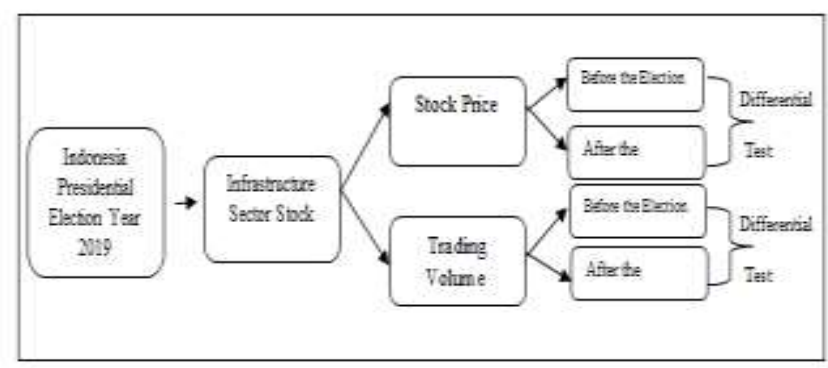

\section{Hypotheses}

Based on the background and theoretical framework, research hypotheses can be formulated as follows :

1. There is no a sigificant difference of stock price before and after the Indonesia Presidential Election year 2019 within infrastructure sector listed on Indonesia Stock Exchange.

2. There is no a sigificant difference of trading volume before and after the Indonesia Presidential Election year 2019 within infrastructure sector listed on Indonesia Stock Exchange.

3. There is no a sigificant difference of stock price before and after the Indonesia Presidential Election year 2019 between infrastructure sector and other sectors listed on Indonesia Stock Exchange.

4. There is no a sigificant difference of trading volume before and after the Indonesia Presidential Election year 2019 between infrastructure sector and other sectors listed on Indonesia Stock Exchange.

\section{Research Methodology \\ Research Design}

The purpose of this study is to analyze the prices and trading volume of infrastructure sector listed on the Indonesia Stock Exchange before and after the Indonesia Presidential Election 2019 by using hypothesis testing. The author used the event study method to study the market reaction to an event that the information was published as an announcement. The extent of researcher interference in this study is minimal interference. The situation in this research is non-contrived. The researcher only intends to analyze. the prices and trading volume of stocks in 2019 presidential election. The units of analysis in this study are all sectors and all companies of Infrastructure subsectors listed on IDX at the period of 2018-2019. The data collected in this study is the stock price and the trading volume of companies from September $21^{\text {st }}, 2018$ until May $24^{\text {th }}$, 2019

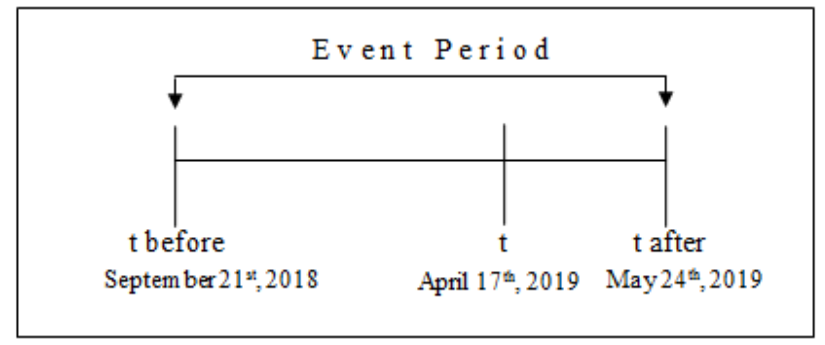

In this study, the time horizon was pooled data/panel data. Pooled data is the combination of cross-sectional and time series. A cross-sectional study is a study that can be undertaken in which data are gathered just once, can be over a period of days, weeks, or months, in order to answer a research question (Sekaran, 2010:119). Time series is a study that involves the sequence of time. This study used pooled data because this study used the stock price and trading volume of some companies in some period of time.

\section{Population}

The population in this research are all sectors 
and all companies of subsectors in Infrastructure Sector that listed in Indonesia Stock Exchange during September $21^{\text {st }}, 2018$ until May $24^{\text {th }}, 2019$, which were 9 sectors and 5 subsectors that consist of 55 companies.

\section{Resource and Data Collection Technique}

Data use in this research is secondary data, which was obtained indirectly through an intermediary medium or obtained and noted by others. The data are obtained from IDX. The secondary data required in this research is daily stock trading data of Infrastructure Sector that make a transaction in IDX within period September 21 $1^{\text {st }}, 2018$ until May $24^{\text {th }}, 2019$. According to the classification of the collection, the type of research data was pooled data, which is the combination of cross-sectional and time series.

Data collection techniques in this research is a documentation method that recorded the data listed on the IDX Monthly Statistics, ICMD ( Indonesia Capital Market Directory ), IDN Financial, and Yahoo Finance for the stock prices and trading volume and some journals associated with this research

\section{Variables Operationalization}

The following section will explain about the operationalization of the variables to be used in research :

1. The stock price is the price of a stock on an ongoing market. If the market is closed, the market price of the stock is the closing price (Marcellyna \& Hartini, 2011). In this case, the stock price is the price for the company contained in the infrastructure sector and other sectors that include in the sectoral index.

2. The volume of stock trading is interpreted as the number of shares that are traded on certain days (Halim and Hidayat, 2010). The active trading of shares, large volume, shows that the shares are favored by the investor. Its also means the stock is fast traded. Trading volume capital markets can be used as an indicator important for investor (Nasution, 2016). Increase in volume stock trading is an increase in buying and selling activities by investors capital market

\section{Analysis Method}

The analysis is performed using the event study method to process and discuss the data obtained. The step before analyzing the data in this study is as follow:

1. Identifying the Presidential Election date, which is April $17^{\text {th }}, 2019$. In order to simplify discussion, the Presidential Election date was identified as day zero $\left(\mathrm{t}_{0}\right)$.

2. Specifying the event period of stock reaction measurement of Presidential Election date Event period that will use 244 days, which consisted of 208 days before the event, one day at the event time, and 36 days after the event. Days before the event start on $21^{\text {st }}$ September $2018{\text { until } 16^{\text {th }}}$ April 2019, which is from the announcement of candidate's names for president and vice president. While days after event start on $18^{\text {th }}$ April 2019 until $24^{\text {th }}$ May 2019, which is until 2 days after the determination of elected president and vice president to monitor the market reaction and avoid Monday effect on stock price and trading volume.Calculating the average of sectors stock price during event period.

3. Calculating average stock price of infrastructure sector during period.

4. Calculating average trading volume of infrastructure sector during period

5. Calculating average stock price of other sectors during period

6. Calculating average trading volume of other sectors during period

\section{Hypothesis Testing Design}

Before doing the t-test, we have to state the null hypotheses as follows:

$\mathrm{H}_{0} 1$ : There is no a sigificant difference of stock price before and after the Indonesia Presidential Election year 2019 within infrastructure sector listed on Indonesia Stock Exchange.

$\mathrm{H}_{0} 2$ : There is no a sigificant difference of trading volume before and after the Indonesia Presidential Election year 2019 within infrastructure sector listed on Indonesia Stock Exchange. 
$\mathrm{H}_{03}$ : There is no a sigificant difference of stock price before and after the Indonesia Presidential Election year 2019 between infrastructure sector and other sectors listed on Indonesia Stock Exchange.

$\mathrm{H}_{0} 4$ : There is no a sigificant difference of trading volume before and after the Indonesia Presidential Election year 2019 between infrastructure sector and other sectors listed on Indonesia Stock Exchange.

For decison-making, in this research performed the following considerations:

1. If the probability $<0.05$; then $\mathrm{H}_{0}$ is rejected, it means that there are differences in variances

2. If the probability > 0.05 ; then $\mathrm{H}_{0}$ cannot be rejected, it means that there is no differences in variance

\section{Research Results and Discussions}

\section{Research Results}

Data analysis was performed using the differential test (t-test), which is the paired sample ttest. Data were processed using SPSS (Statistical Package for Social Science)

\section{Stock Price}

\section{Infrastructure Sector}

Table 4.1

Descriptive Statistics of Stock Price for Energy Subsector

\begin{tabular}{|l|l|l|l|c|c|}
\hline & & Mean & N & $\begin{array}{c}\text { Std. } \\
\text { Deviation }\end{array}$ & $\begin{array}{c}\text { Std. Error } \\
\text { Mean }\end{array}$ \\
\hline Pair & Price_Energy_before & 748.1675 & 7 & 747.49816 & 282.5277 \\
1 & Price_Energy_after & 702.1279 & 7 & 704.18266 & 266.1560 \\
\hline
\end{tabular}

Sources : Data processed (2019)

Table 4.1 shows the average (mean) of stock price of companies for energy subsector listed on Indonesia Stock Exchange:

1. The average of stock price before the presidential election is 748.17

2. The average of stock price after the presidential election is 702.13

The table shows that the average of stock price before and after the Presidential Election decrease.

\section{Table 4.2}

Descriptive Statistics of Stock Price for Highways,

\begin{tabular}{|l|l|c|c|c|c|}
\multicolumn{7}{|c}{ Airports, and Ports Subsector } \\
\hline & Mean & N & $\begin{array}{c}\text { Std. } \\
\text { Deviation }\end{array}$ & $\begin{array}{c}\text { Std. } \\
\text { Error } \\
\text { Mean }\end{array}$ \\
\hline $\begin{array}{l}\text { Pair } \\
1\end{array}$ & $\begin{array}{l}\text { Price_ } \\
\text { Highways,airports,and } \\
\text { ports_before } \\
\text { Price_ } \\
\text { Highways,airports,and } \\
\text { ports_after }\end{array}$ & 2099.382 & 3 & 2355.03 & 1359.680 \\
\hline
\end{tabular}

Sources : Data processed (2019)

Table 4.2 shows the average (mean) of stock price of companies for highways, airports, and ports subsector listed on Indonesia Stock Exchange :

1. The average of stock price before the presidential election is 2099.382

2. The average of stock price after the presidential election is 2358.072

The table shows that the average of stock price before and after the Presidential Election increase.

Table 4.3

Descriptive Statistics of Stock Price for Telecommunication Subsector

\begin{tabular}{|l|l|c|c|c|c|}
\hline & & Mean & N & $\begin{array}{c}\text { Std. } \\
\text { Deviation }\end{array}$ & $\begin{array}{c}\text { Std. } \\
\text { Error } \\
\text { Mean }\end{array}$ \\
\hline $\begin{array}{l}\text { Pair } \\
1\end{array}$ & $\begin{array}{l}\text { Price__ } \\
\text { Telecommunication_ } \\
\text { before } \\
\text { Price_ } \\
\text { Telecommunication_after }\end{array}$ & 1794.544 & 5 & 1630.304 & 729.0940 \\
\hline
\end{tabular}

Sources : Data processed (2019)

Table 4.3 shows the average (mean) of stock price of companies for telecommunication subsector listed on Indonesia Stock Exchange :

1. The average of stock price before the presidential election is 1784.54

2. The average of stock price after the presidential election is 1799.47

The table shows that the average of stock price before and after the Presidential Election increase.

Table 4.4

Descriptive Statistics of Stock Price for Transportation Subsector

\begin{tabular}{|l|l|c|c|c|c|}
\hline & & Mean & N & \multicolumn{1}{c|}{$\begin{array}{c}\text { Std. } \\
\text { Deviation }\end{array}$} & $\begin{array}{c}\text { Std. Error } \\
\text { Mean }\end{array}$ \\
\hline $\begin{array}{l}\text { Pair } \\
1\end{array}$ & $\begin{array}{l}\text { Price__ } \\
\text { Transportation_ } \\
\text { before }\end{array}$ & 481.1753 & 32 & 796.79713 & 140.8552 \\
& $\begin{array}{l}\text { Price_ } \\
\text { Transportation_after }\end{array}$ & 516.2588 & 32 & 929.60264 & 164.3321 \\
\hline
\end{tabular}

Sources : Data processed (2019) 
Table 4.4 shows the average (mean) of stock price of companies for transportation subsector listed on Indonesia Stock Exchange :

1. The average of stock price before the presidential election is 481.17

2. The average of stock price after the presidential election is $\mathbf{5 1 6 . 2 6}$

The table shows that the average of stock price before and after the Presidential Election increase.

\section{Table 4.5}

Descriptive Statistics of Stock Price for Non Building Construction Subsector

\begin{tabular}{|l|l|c|c|c|c|}
\hline & & Mean & N & $\begin{array}{c}\text { Std. } \\
\text { Deviation }\end{array}$ & $\begin{array}{c}\text { Std. Error } \\
\text { Mean }\end{array}$ \\
\hline $\begin{array}{l}\text { Pair } \\
1\end{array}$ & $\begin{array}{l}\text { Price_Non building } \\
\text { construction_before } \\
\text { Price_Non building } \\
\text { construction_after }\end{array}$ & 2384.666 & 8 & 2618.871 & 925.9107 \\
\hline
\end{tabular}

Sources : Data processed (2019)

Table 4.5 shows the average (mean) of stock price of companies for non building construction subsector listed on Indonesia Stock Exchange :

1. The average of stock price before the presidential election is 2384.66

2. The average of stock price after the presidential election is 2261.39

The table shows that the average of stock price before and after the Presidential Election decrease.

The average stock price of each subsector shows an increase and decrease. Based on the results obtained, there are three sub-sectors that experienced an increase in the average stock price, namely highways, airports, and ports subsector; telecommunication subsector; and transportation subsector. While the rest, energy subsector and nonbuilding construction subsector are decreased. So that it can be concluded that the average share price of the infrastructure subsectors has increased. This can also be proven by a test conducted directly on the five sub-sectors, namely in 55 companies directly. The results of the test can be seen in table 4.6

Table 4.6

Descriptive Statistics of Stock Price for All Infrastructure Sectors

\begin{tabular}{|l|l|l|l|l|c|}
\hline & Mean & $\mathrm{N}$ & $\begin{array}{c}\text { Std. } \\
\text { Deviation }\end{array}$ & $\begin{array}{c}\text { Std. Error } \\
\text { Mean }\end{array}$ \\
\hline
\end{tabular}

\begin{tabular}{|l|l|l|l|l|l|}
\hline Pair & Price__ & 998.7814 & 55 & 1514.539 & 204.2204 \\
& subsector_before & 1010.871 & 55 & 1578.844 & 212.8913 \\
\hline
\end{tabular}

Sources : Data processed (2019)

Table 4.6 shows the average (mean) of stock price of companies for infrrastructure subsectors listed on Indonesia Stock Exchange :

1. The average of stock price before the presidential election is 998.78

2. The average of stock price after the presidential election is 1010.87

The table shows that the average of stock price before and after the Presidential Election increase.

\section{Sector}

Table 4.7

Descriptive Statistics of Stock Price for Other Sectors

\begin{tabular}{|c|c|c|c|}
\hline & & & $\begin{array}{c}\text { Price } \\
\text { _Infrastructur_- } \\
\text { Sector }\end{array}$ \\
\hline \multirow{6}{*}{$\begin{array}{l}\text { Test Value }= \\
55.968\end{array}$} & \multicolumn{2}{|l|}{$\mathrm{t}$} & -1.978 \\
\hline & \multicolumn{2}{|l|}{$\mathrm{df}$} & 54 \\
\hline & \multicolumn{2}{|l|}{ Sig. (2-tailed) } & .053. \\
\hline & \multicolumn{2}{|l|}{ Mean Difference } & -68.05762 \\
\hline & $95 \% \quad$ Confidenccen & Lower & -137.0530 \\
\hline & $\begin{array}{l}\text { Internal Of the } \\
\text { Difference }\end{array}$ & Upper & .9378 \\
\hline
\end{tabular}

Table 4.7 shows the average (mean) of stock price of companies for other sectors listed on Indonesia Stock Exchange before and after the Presidential Election year 2019 is decreased by 55.968 .

\section{Trading Volume}

Infrastructur Sector

Tabel 4.8

Descriptive Statistics of Trading Volume for Energy Subsector

\begin{tabular}{|l|l|c|c|c|c|}
\hline & & Mean & N & $\begin{array}{c}\text { Std. } \\
\text { Deviation }\end{array}$ & $\begin{array}{c}\text { Std. Error } \\
\text { Mean }\end{array}$ \\
\hline $\begin{array}{l}\text { Pair } \\
1\end{array}$ & $\begin{array}{l}\text { Volume__ } \\
\text { Energy_before } \\
\begin{array}{l}\text { Volume__ } \\
\text { Energy_after }\end{array}\end{array}$ & 14645611.9 & 7 & 27727044 & 10479837.52 \\
\hline
\end{tabular}

Sources : Data processed (2019)

Table 4.8 shows the average (mean) of trading volume of companies for energy subsector listed on Indonesia Stock Exchange : 
1. The average of trading volume before the presidential election is 14645611.9

2. The average of trading volume after the presidential election is 10941390.3

The table shows that the average of trading volume before and after the Presidential Election decrease.

Tabel 4.9

\section{Descriptive Statistics of Trading Volume for}

Highways, Airports, and Ports Subsector

\begin{tabular}{|l|l|c|c|c|c|}
\hline & & Mean & N & $\begin{array}{c}\text { Std. } \\
\text { Deviation }\end{array}$ & $\begin{array}{c}\text { Std. Error } \\
\text { Mean }\end{array}$ \\
\hline 1 & $\begin{array}{l}\text { Poirume__ } \\
\text { Highways,airports,and } \\
\text { ports_before }\end{array}$ & 2612995 & 3 & 3393079 & 1958995 \\
$\begin{array}{l}\text { Volume__ } \\
\text { Highways,airports,and } \\
\text { ports_after }\end{array}$ & 2155824 & 3 & 3367733 & 1944362 \\
\hline
\end{tabular}

Sources : Data processed (2019)

Table 4.9 shows the average (mean) of trading volume of companies for highways, airports, and ports subsector listed on Indonesia Stock Exchange :

1. The average of trading volume before the presidential election is 2612995

2. The average of trading volume after the presidential election is 2155824

The table shows that the average of trading volume before and after the Presidential Election decrease.

Table 4.10

Descriptive Statistics of Trading Volume for Telecommunication Subsector

\begin{tabular}{|l|l|c|c|c|c|}
\hline & & Mean & N & $\begin{array}{c}\text { Std. } \\
\text { Deviation }\end{array}$ & $\begin{array}{c}\text { Std. Error } \\
\text { Mean }\end{array}$ \\
\hline $\begin{array}{l}\text { Pair } \\
1\end{array}$ & $\begin{array}{l}\text { Volume__ } \\
\text { Telecommunication } \\
\text { _before } \\
\begin{array}{l}\text { Volume__ } \\
\text { Telecommunication } \\
\text { after }\end{array}\end{array}$ & 44809407.938 & 5 & 53999193 & 24149173.4 \\
\hline
\end{tabular}

Sources : Data processed (2019)

Table 4.10 shows the average (mean) of trading volume of companies for telecommunication subsector listed on Indonesia Stock Exchange :

1. The average of trading volume before the presidential election is 44809407.9

2. The average of trading volume after the presidential election is 42566586.4

The table shows that the average of trading volume before and after the Presidential Election decrease.

Table 4.11

Descriptive Statistics of Trading Volume for Transportation Subsector

\begin{tabular}{|l|l|c|c|c|c|}
\hline & & Mean & N & $\begin{array}{c}\text { Std. } \\
\text { Deviation }\end{array}$ & $\begin{array}{c}\text { Std. Error } \\
\text { Mean }\end{array}$ \\
\hline $\begin{array}{l}\text { Pair } \\
1\end{array}$ & $\begin{array}{l}\text { Volume__ } \\
\text { Transportation_before }\end{array}$ & 21771393.92 & 32 & 92892543.9 & 16421236.9 \\
& $\begin{array}{l}\text { Volume_- } \\
\text { Transportation_after }\end{array}$ & 43938682.13 & 32 & 210015228 & 37125798.0 \\
\hline
\end{tabular}

Table 4.11 shows the average (mean) of trading volume of companies variable for transportation subsector listed on Indonesia Stock Exchange :

1. The average of trading volume before the presidential election is 21771393.92

2. The average of trading volume after the presidential election is 43938682.13

The table shows that the average of trading volume before and after the Presidential Election increase.

Table 4.12

Descriptive Statistics of Trading Volume for Non Building Construction Subsector

\begin{tabular}{|l|l|c|c|c|c|}
\hline & & Mean & N & $\begin{array}{c}\text { Std. } \\
\text { Deviation }\end{array}$ & $\begin{array}{c}\text { Std. Error } \\
\text { Mean }\end{array}$ \\
\hline $\begin{array}{l}\text { Pair } \\
1\end{array}$ & $\begin{array}{l}\text { Volume_Non building } \\
\text { construction_before } \\
\text { Volume_Non building } \\
\text { construction_after }\end{array}$ & 5481388 & 8 & 8140050 & 2877942 \\
\hline
\end{tabular}

Sources : Data processed (2019)

Table 4.12 shows the average (mean) of trading volume of companies for non building construction subsector listed on Indonesia Stock Exchange :

1. The average of trading volume before the presidential election is 5481388

2. The average of trading volume after the presidential election is 4931749

The table shows that the average of trading volume before and after the Presidential Election decrease.

The average trading volume of each subsector shows an increase and decrease. Based on the results obtained, there is only one sub-sectors that experienced an increase in the average trading 
volume, namely transportation subsector. While energy subsector, highways, airports, and ports subsector; telecommunication subsector; and nonbuilding construction subsector are decreased. Although more of subsectors are decrease, but even though there were four subsectors which experienced a decline and only subsector experienced an increase, the number of companies that experienced an increase in volume trading was more than the decline. So conclusions can be taken after testing the 55 companies found in all sub-sectors. The results of the test can be seen in table 4.13

Table 4.13

Descriptive Statistics of Trading Volume for All Infrastructure Sector

\begin{tabular}{|l|l|c|c|c|c|}
\hline & & Mean & N & $\begin{array}{c}\text { Std. } \\
\text { Deviation }\end{array}$ & $\begin{array}{c}\text { Std. Error } \\
\text { Mean }\end{array}$ \\
\hline $\begin{array}{l}\text { Pair } \\
1\end{array}$ & $\begin{array}{l}\text { Volume_subsector } \\
\text { before } \\
\text { Volume_subsector } \\
\text { after }\end{array}$ & 19544382.152 & 55 & 73311039.3 & 9885258.5 \\
\hline
\end{tabular}

Sources : Data processed (2019)

Table 4.13 shows the average (mean) of trading volume of companies for all infrastructure subsectors listed on Indonesia Stock Exchange :

1. The average of trading volume before the presidential election is 19544382.15

2. The average of trading volume after the presidential election is 31661490.11

The table shows that the average of trading volume before and after the Presidential Election increase.

\section{Other Sectors}

Table 4.14

Descriptive Statistics of Trading Volume for Other Sectors

\begin{tabular}{|c|c|c|c|}
\hline & & & $\begin{array}{c}\text { Price } \\
\text { _Infrastructur_ } \\
\text { Sector }\end{array}$ \\
\hline \multirow{6}{*}{$\begin{array}{l}\text { Test Value }= \\
384873735.80\end{array}$} & \multirow{2}{*}{\multicolumn{2}{|c|}{$\begin{array}{l}\mathrm{t} \\
\mathrm{df}\end{array}$}} & 30.543 \\
\hline & & & 54 \\
\hline & \multicolumn{2}{|l|}{ Sig. (2-tailed) } & .000 \\
\hline & \multicolumn{2}{|l|}{ Mean Difference } & 372756627.84255 \\
\hline & 95\% Confidenccen & Lower & 348288373.8747 \\
\hline & $\begin{array}{l}\begin{array}{l}\text { Internal } \\
\text { Difference }\end{array} \\
\end{array}$ & Upper & 397224881.8104 \\
\hline
\end{tabular}

Table 4.14 shows the average (mean) of trading volume of companies for other sectors listed on Indonesia Stock Exchange before and after the Presidential Election year 2019 is increased by 384873735.80 .

\section{Discussions}

\section{$1^{\text {st }}$ Hypothesis Discussion}

The first hypothesis in this study is - There is no a sigificant difference of stock price before and after the Indonesia Presidential Election year 2019 within infrastructure sector listed on Indonesia Stock Exchangell. In this hypothesis, the data consist of the 5 subsectors of infrastructure sector.

\section{Energy Subsector}

Tabel 4.15

Paired Sample T-Test of Stock Price for Energy Subsector

\begin{tabular}{|c|c|c|c|}
\hline & & & $\begin{array}{c}\text { Pair 1 } \\
\text { Price_Energy_before } \\
\text { - Price_Energy_after }\end{array}$ \\
\hline \multirow{5}{*}{$\begin{array}{l}\text { Paired } \\
\text { Differences }\end{array}$} & \multirow{3}{*}{\multicolumn{2}{|c|}{$\begin{array}{l}\text { Mean } \\
\text { Std. Deviation } \\
\text { Std. Error Mean }\end{array}$}} & 46.03965 \\
\hline & & & 71.53196 \\
\hline & & & 27.03654 \\
\hline & \multirow{2}{*}{$\begin{array}{ll}95 \% & \text { Confidenccen } \\
\text { Internal Of the } \\
\text { Difference }\end{array}$} & \multirow{2}{*}{$\begin{array}{l}\text { Lower } \\
\text { Upper }\end{array}$} & -20.11638 \\
\hline & & & 112.19567 \\
\hline $\mathrm{t}$ & & & 1.703 \\
\hline df & & & 6 \\
\hline Sig. (2-tailed) & & & .139 \\
\hline
\end{tabular}

Sources : Data processed (2019)

Paired sample t-test of stock price for all sectors shows t-value is 1.703 with significance (sig) 0.139. Because the signifance of $0.139>0.05$, the interference taken is the stock price for energy subsector has no significant differences before and after the presidential election.

\section{Highways, Airports, and Ports Subsector}

Tabel 4.16

Paired Sample T-Test of Stock Price for Highways, Airports, and Ports Subsector

\begin{tabular}{|c|c|c|c|}
\hline & & & $\begin{array}{c}\text { Pair 1 } \\
\text { Highways,airports,and } \\
\text { ports_before - Price_ } \\
\text { Highways,airports,and } \\
\text { ports_after }\end{array}$ \\
\hline \multirow{5}{*}{$\begin{array}{l}\text { Paired } \\
\text { Differences }\end{array}$} & \multirow{3}{*}{\multicolumn{2}{|c|}{$\begin{array}{l}\text { Mean } \\
\text { Std. Deviation } \\
\text { Std. Error Mean }\end{array}$}} & -258.68994 \\
\hline & & & 553.87014 \\
\hline & & & 319.77708 \\
\hline & \multirow{4}{*}{$\begin{array}{l}95 \% \text { Confidenccen } \\
\text { Internal Of the } \\
\text { Difference }\end{array}$} & Lower & -1634.57965 \\
\hline & & Upper & 1117.19976 \\
\hline $\mathrm{t}$ & & & -.809 \\
\hline df & & & 2 \\
\hline
\end{tabular}


Sig. (2-tailed)

Sources : Data processed (2019)

Paired sample t-test of stock price for all sectors shows t-value is -0.809 with significance ( $\mathrm{sig}$ ) 0.503 . Because the signifance of $0.503>0.05$, the interference taken is the stock price for highways, airports, and ports subsector has no significant differences before and after the presidential election.

\section{Telecommunication Subsector}

Tabel 4.17

Paired Sample T-Test of Stock Price for Telecommunication Subsector

\begin{tabular}{|c|c|c|c|}
\hline & & & $\begin{array}{c}\text { Pair 1 } \\
\text { Telecommunication_ } \\
\text { before - Price_ } \\
\text { Telecommunication_after }\end{array}$ \\
\hline \multirow{5}{*}{$\begin{array}{l}\text { Paired } \\
\text { Differences }\end{array}$} & & -14.92701 \\
\hline & \multirow{2}{*}{\multicolumn{2}{|c|}{$\begin{array}{l}\text { Std. Deviation } \\
\text { Std. Error Mean }\end{array}$}} & 287.49000 \\
\hline & & & 128.56944 \\
\hline & \multirow{5}{*}{$\begin{array}{l}95 \% \text { Confidenccen } \\
\text { Internal Of the } \\
\text { Difference }\end{array}$} & Lower & -371.89299 \\
\hline & & Upper & 342.03897 \\
\hline $\mathrm{t}$ & & & -.116 \\
\hline df & & & 4 \\
\hline Sig. (2-tailed) & & & .913 \\
\hline
\end{tabular}

Sources : Data processed (2019)

Paired sample t-test of stock price for telecommunication subsector shows t-value is -0.116 with significance (sig) 0.913 . Because the signifance of $0.913>0.05$, the interference taken is the stock price for telecommunication has no significant differences before and after the presidential election.

\section{Transportation Subsector}

Table 4.18

Wilcoxon Signed Rank Test (T-Test) for Transportation Subsector

\begin{tabular}{|l|c|}
\hline & $\begin{array}{c}\text { Price_Transportation } \\
\text { _after - Price_Transportation } \\
\text { _before }\end{array}$ \\
\hline Z & $-.463^{\mathrm{a}}$ \\
Asymp. Sig. (2-tailed) & .644 \\
\hline
\end{tabular}

a. Based on negative ranks.

b. Wilcoxon Signed Ranks Test
Paired sample t-test of stock price for transportation subsector shows significance (sig) 0.644. Because the signifance of $0.644>0.05$, the interference taken is the stock price for transportation has no significant differences before and after the presidential election.

\section{Non Building Construction Subsector}

Table 4.19

Paired Sample T-Test of Stock Price for No Building Construction Subsector

\begin{tabular}{|c|c|c|c|}
\hline & & & $\begin{array}{c}\text { Pair 1 } \\
\text { Telecommunication__ } \\
\text { before - Price_ } \\
\text { Telecommunication_after }\end{array}$ \\
\hline \multirow{5}{*}{$\begin{array}{l}\text { Paired } \\
\text { Differences }\end{array}$} & \multirow{3}{*}{\multicolumn{2}{|c|}{$\begin{array}{l}\text { Mean } \\
\text { Std. Deviation } \\
\text { Std. Error Mean }\end{array}$}} & 123.27000 \\
\hline & & & 434.67117 \\
\hline & & & 153.67947 \\
\hline & \multirow{2}{*}{$\begin{array}{l}95 \% \text { Confidenccen } \\
\text { Internal Of the } \\
\text { Difference }\end{array}$} & Lower & -240.12419 \\
\hline & & Upper & 486.66419 \\
\hline $\mathrm{t}$ & & & .802 \\
\hline df & & & 7 \\
\hline Sig. (2-tailed) & & & .449 \\
\hline
\end{tabular}

Sources : Data processed (2019)

Paired sample t-test of stock price for telecommunication subsector shows t-value is 0.802 with significance (sig) 0.449 . Because the signifance of $0.449>0.05$, the interference taken is the stock price for telecommunication has no significant differences before and after the presidential election. Paired sample t-test of stock price for each subsector shows no significant differences before and after the presidential election. From the result, the interference taken was accepted the alternative hypothesis - There is no a sigificant difference of stock price before and after the Indonesia Presidential Election year 2019 within infrastructure sector listed on Indonesia Stock Exchangell. This can also be proven by a test conducted directly on the five sub-sectors, namely in 55 companies directly. The results of the test can be seen in table 4.20 
Table 4.20

Paired Sample T-Test of Stock Price for All Infrastructure Sector

\begin{tabular}{|c|c|c|c|}
\hline & & & $\begin{array}{c}\text { Pair 1 } \\
\text { Price_subsector_before } \\
\text { - Price_subsector_after }\end{array}$ \\
\hline \multirow{5}{*}{$\begin{array}{l}\text { Paired } \\
\text { Differences }\end{array}$} & Mean & & -12.08980 \\
\hline & Std. Deviation & & 255.21888 \\
\hline & Std. Error Mean & & 34.41371 \\
\hline & 95\% Confidenccen & Lower & -81.08513 \\
\hline & $\begin{array}{l}\text { Internal Of the } \\
\text { Difference }\end{array}$ & Upper & 56.90552 \\
\hline $\mathrm{t}$ & & & -.351 \\
\hline df & & & 54 \\
\hline Sig. (2-tailed) & & & .727 \\
\hline
\end{tabular}

Sources : Data processed (2019)

Paired sample t-test of stock price for all subsectors shows $\mathrm{t}$-value is -0.351 with significance (sig) 0.727. Because the signifance of $0.727>0.05$, the interference taken is the stock price for all subsectors has no significant differences before and after the presidential election. Negative value (-) on tvalue shows that the average stock price before the presidential election year 2019 lower than the average stock price after the presidential election.

\section{$2^{\text {nd }}$ Hypothesis Discussion}

The second hypothesis in this study is - There is no a sigificant difference of trading volume before and after the Indonesia Presidential Election year 2019 within infrastructure sector listed on Indonesia Stock Exchangell. In this hypothesis, the data consist of the 5 subsector of infrastructure sector. So, the steps of analysis are started by normality test. Normallity test used because we need to know whether two variables data of stock price were normally distributed or not. Kolmogorov-Smirnov test used to test the normality of the data by using SPSS Software. Then the hypothesis can be used to test by using paired sample t-test.

\section{Energy Subsector} rules :

Kolmogrov-Smirnov test used the following

1. If the significance $\leq 0.05$ then the data was abnormally distributed.

2. If the significance $>0.05$ then the data was normally distributed

Table 4.21

Trading Volume of Energy Subsector Normality

\begin{tabular}{|c|c|c|c|}
\hline & & $\begin{array}{c}\text { Volume_- } \\
\text { Energy_Before }\end{array}$ & $\begin{array}{c}\text { Volume_- } \\
\text { Energy_after }\end{array}$ \\
\hline \multicolumn{2}{|l|}{$\mathrm{N}$} & 7 & 7 \\
\hline \multirow[t]{2}{*}{ Normal Parameters $\mathrm{a}, \mathrm{b}$} & Mean & 14645611.94 & 10941390.29 \\
\hline & $\begin{array}{l}\text { Std. } \\
\text { Deviation }\end{array}$ & 27727043.87 & 16872867.82 \\
\hline \multirow{3}{*}{$\begin{array}{l}\text { Most Extreme } \\
\text { Differences } \\
t\end{array}$} & Absolute & .372 & .372 \\
\hline & Positive & .372 & .372 \\
\hline & Negetive & -.299 & -.258 \\
\hline Kolmogorov-Smirnov Z & & .984 & .984 \\
\hline Asymp. Sig. (2-tailed) & & .288 & .288 \\
\hline
\end{tabular}

Sources : Data processed (2019)

Table 4.21 shows $\mathrm{Z}$-value of each trading volume as:

1. Z-value for trading volume variable before the Presidential Election is 0.984 with the signifance (sig) 0.288. Because the significance is $0.288>0.05$, then the interference taken is the trading volume data before the Presidential Election was normally distributed.

2. Z-value for trading volume variable after the Presidential Election is 0.984 with the signifance (sig) 0.288. Because the significance is $0.288>0.05$, then the interference taken is the trading volume data after the Presidential Election was normally distributed.

From the normality test, it can be concluded that the data on average trading volume before and after the presidential election were normally distributed. Therefore, it can be used to test the hypothesis by using paired sample t-test.

Table 4.22

Paired Sample T-Test of Stock Price for Energy Subsector

\begin{tabular}{|c|c|c|c|}
\hline & & & $\begin{array}{c}\text { Pair 1 } \\
\text { Volume_Energy_before } \\
\text { - Volume_Energy_after }\end{array}$ \\
\hline \multirow{5}{*}{$\begin{array}{l}\text { Paired } \\
\text { Differences }\end{array}$} & \multirow{3}{*}{\multicolumn{2}{|c|}{$\begin{array}{l}\text { Mean } \\
\text { Std. Deviation } \\
\text { Std. Error Mean }\end{array}$}} & 3704221.65286 \\
\hline & & & 16544938.69899 \\
\hline & & & 6253399.03633 \\
\hline & \multirow{5}{*}{$\begin{array}{l}95 \% \text { Confidenccen } \\
\text { Internal Of the } \\
\text { Difference }\end{array}$} & Lower & -11597294.55909 \\
\hline & & Upper & 19005737.86480 \\
\hline $\mathrm{t}$ & & & .592 \\
\hline & & & 6 \\
\hline Sig. (2-tailed) & & & .575 \\
\hline
\end{tabular}

Sources : Data processed (2019)

Paired sample t-test of trading volume for 
energy subsectors shows t-value is 0.592 with significance (sig) 0.575. Because the signifance of $0.575>0.05$, the interference taken is the trading volume for energy subsector has no significant differences before and after the presidential election. Positive value $(+)$ on t-value shows that the average trading volume before the presidential election year 2019 higher than the average trading volume after the presidential election.

\section{Highways, Airports, and Ports Subsector}

Kolmogrov-Smirnov test used the following rules :

1. If the significance $\leq 0.05$ then the data was abnormally distributed.

2. If the significance $>0.05$ then the data was normally distributed.

Table 4.23

Trading Volume of Highways, Airports, and Ports Subsector Normality Tes

\begin{tabular}{|ll|r|r|}
\hline & $\begin{array}{c}\text { Volume__ } \\
\text { Highways,air } \\
\text { ports,and ports } \\
\text { _Before }\end{array}$ & $\begin{array}{c}\text { Volume__ } \\
\text { Highways,air } \\
\text { ports,and ports } \\
\text { _after }\end{array}$ \\
\hline $\mathrm{N}$ & 3 & 3 \\
Normal Parameters a,b & Mean & 2612995.20 & 2155824.0 \\
& Std. & 3393079.34 & 3367733.2 \\
Most Extreme & Deviation & .316 & .384 \\
Differences & Absolute & .316 & .384 \\
$\mathrm{t}$ & Positive & -.226 & -.281 \\
Kolmogorov-Smirnov Z & Negetive & .547 & .666 \\
Asymp. Sig. (2-tailed) & & .925 & .767 \\
\hline
\end{tabular}

Sources : Data processed (2019)

Table 4.23 shows $\mathrm{Z}$-value of each trading volume as:

1. Z-value for trading volume variable before the Presidential Election is 0.547 with the signifance (sig) 0.925. Because the significance is 0.925 $>0.05$, then the interference taken is the trading volume data before the Presidential Election was normally distributed.

2. Z-value for trading volume variable after the Presidential Election is 0.666 with the signifance (sig) 0.767. Because the significance is 0.767 $>0.05$, then the interference taken is the trading volume data after the Presidential Election was normally distributed.

From the normality test, it can be concluded that the data on average trading volume before and after the presidential election were normally distributed. Therefore, it can be used to test the hypothesis by using paired sample t-test.

Table 4.24

Paired Sample T-Test of Stock Price for Highways, Airports, and Ports Subsector

\begin{tabular}{|c|c|c|c|}
\hline & & & $\begin{array}{c}\text { Pair } 1 \text { Highways,airports,and } \\
\text { ports_before - Volume_ } \\
\text { Highways,airports, and ports } \\
\text { _after }\end{array}$ \\
\hline \multirow{5}{*}{$\begin{array}{l}\text { Paired } \\
\text { Differences }\end{array}$} & \multicolumn{2}{|l|}{ Mean } & 457171.20333 \\
\hline & \multirow{2}{*}{\multicolumn{2}{|c|}{$\begin{array}{l}\text { Std. Deviation } \\
\text { Std. Error Mean }\end{array}$}} & 620131.24779 \\
\hline & & & 358032.94285 \\
\hline & \multirow{2}{*}{$\begin{array}{l}95 \% \text { Confidenccen } \\
\text { Internal Of the } \\
\text { Difference }\end{array}$} & Lower & -1083320.21554 \\
\hline & & Upper & 1997662.62221 \\
\hline $\mathrm{t}$ & & & 1.277 \\
\hline df & & & 2 \\
\hline Sig. (2-tailed) & & & .330 \\
\hline
\end{tabular}

Sources : Data processed (2019)

Paired sample t-test of trading volume for highways, airports, and ports subsectors shows t-value is 1.227 with significance (sig) 0.330 . Because the signifance of $0.330>0.05$, the interference taken is the trading volume for highways, airports, and ports subsectors has no significant differences before and after the presidential election. Positive value $(+)$ on tvalue shows that the average trading volume before the presidential election year 2019 higher than the average trading volume after the presidential election.

\section{Telecommunication Subsector}

Kolmogrov-Smirnov test used the following rules :

1. If the significance $\leq 0.05$ then the data was abnormally distributed.

2. If the significance $>0.05$ then the data was normally distributed

Tabel 4.25

\section{Telecommunication Subsector Normality Test}

\begin{tabular}{|c|c|c|c|}
\hline & & $\begin{array}{c}\text { Volume_ } \\
\text { Telecommuni } \\
\text { cation_Before }\end{array}$ & $\begin{array}{l}\text { Volume_ } \\
\text { Telecommuni } \\
\text { cation_after }\end{array}$ \\
\hline $\mathrm{N}$ & & 5 & 5 \\
\hline \multirow[t]{2}{*}{ Normal Parameters $a, b$} & Mean & 44809407.94 & 42566586.4 \\
\hline & $\begin{array}{l}\text { Std. } \\
\text { Deviation }\end{array}$ & 53999193.31 & 50480187.7 \\
\hline \multirow{3}{*}{$\begin{array}{l}\text { Most Extreme } \\
\text { Differences } \\
\mathrm{t}\end{array}$} & Absolute & .296 & .309 \\
\hline & Positive & .296 & .309 \\
\hline & Negetive & -.203 & -.200 \\
\hline Kolmogorov-Smirnov Z & & .662 & .692 \\
\hline Asymp. Sig. (2-tailed) & & .773 & .725 \\
\hline
\end{tabular}


Sources : Data processed (2019)

Table 4.25 shows $\mathrm{Z}$-value of each trading volume as:

1. Z-value for trading volume variable before the Presidential Election is 0.662 with the signifance (sig) 0.773. Because the significance is $0.773>0.05$, then the interference taken is the trading volume data before the Presidential Election was normally distributed.

2. Z-value for trading volume variable after the Presidential Election is 0.692 with the signifance (sig) 0.725 . Because the significance is $0.725>$ 0.05 , then the interference taken is the trading volume data after the Presidential Election was normally distributed.

From the normality test, it can be concluded that the data on average trading volume before and after the presidential election were normally distributed. Therefore, it can be used to test the hypothesis by using paired sample t-test.

Table 4.26

Paired Sample T-Test of Stock Price for Telecommunication Subsector

\begin{tabular}{|c|c|c|c|}
\hline & & & $\begin{array}{c}\text { Pair 1 } \\
\text { Volume_- } \\
\text { Telecommunication_ } \\
\text { before - Volume_ } \\
\text { Telecommunication_after }\end{array}$ \\
\hline \multirow{5}{*}{$\begin{array}{l}\text { Paired } \\
\text { Differences }\end{array}$} & & 2242821.53800 \\
\hline & \multirow{2}{*}{\multicolumn{2}{|c|}{$\begin{array}{l}\text { Std. Deviation } \\
\text { Std. Error Mean }\end{array}$}} & 10129604.51521 \\
\hline & & & 4530096.85624 \\
\hline & 95\% Confidenccen & Lower & -10334743.70457 \\
\hline & $\begin{array}{l}\text { Internal Of the } \\
\text { Difference }\end{array}$ & Upper & 14820386.78057 \\
\hline \multicolumn{3}{|l|}{$\mathrm{t}$} & .495 \\
\hline & 4 \\
\hline \multicolumn{3}{|l|}{ Sig. (2-tailed) } & .646 \\
\hline
\end{tabular}

Sources : Data processed (2019)

Paired sample t-test of trading volume for telecommunication subsectors shows t-value is 0.495 with significance (sig) 0.646 . Because the signifance of $0.646>0.05$, the interference taken is the trading volume for telecommunication subsectors has no significant differences before and after the presidential election. Positive value $(+)$ on $t$-value shows that the average trading volume before the presidential election year 2019 higher than the average trading volume after the presidential election.

\section{Transportation Subsector}

Kolmogrov-Smirnov test used the following rules :

1. If the significance $\leq 0.05$ then the data was abnormally distributed.

2. If the significance $>0.05$ then the data was normally distributed

Tabel 4.27

Trading Volume of Transportation Subsector Normality Test

\begin{tabular}{|c|c|c|c|}
\hline & & $\begin{array}{l}\text { Volume_- } \\
\text { Transportati } \\
\text { on_Before }\end{array}$ & $\begin{array}{c}\text { Volume__ }_{\text {Transportati on }} \\
\text { after }\end{array}$ \\
\hline \multicolumn{2}{|l|}{$\mathrm{N}$} & 32 & 32 \\
\hline \multirow[t]{2}{*}{ Normal Parameters $a, b$} & Mean & 21771394 & 43938682 \\
\hline & $\begin{array}{l}\text { Std. } \\
\text { Deviation }\end{array}$ & 92892544 & 210015228 \\
\hline \multirow{3}{*}{$\begin{array}{l}\text { Most Extreme } \\
\text { Differences } \\
\text { t }\end{array}$} & Absolute & .420 & .437 \\
\hline & Positive & .420 & 437 \\
\hline & Negetive & -.407 & -.417 \\
\hline Kolmogorov-Smirnov Z & & 2.375 & 2.469 \\
\hline Asymp. Sig. (2-tailed) & & .000 & .000 \\
\hline
\end{tabular}

Sources : Data processed (2019)

Table 4.27 shows $\mathrm{Z}$-value of each trading volume as:

1. Z-value for stock price variable before the Presidential Election is 2.375 with the signifance (sig) 0.000 . Because the significance is $0.000<$ 0.05 , then the interference taken is the stock price data before the Presidential Election was not normally distributed.

2. Z-value for stock price variable after the Presidential Election is 2.469 with the signifance (sig) 0.000. Because the significance is $0.000<$ 0.05 , then the interference taken is the stock price data after the Presidential Election was not normally distributed

From the normality test, it can be concluded that the data on average trading volume before and after the presidential election were not normally distributed. For the alternative, the author tested the data using Wilcoxon Signed Rank Test. The SignWilcoxon test is a test to determine whether there is a difference between two dependent or paired samples and is used as an alternative to the Paired Sample T Test if the data are not normally distributed 
Table 4.28

Wilcoxon Signed Rank Test for Transportation Subsecto

\begin{tabular}{ll|r|r|r}
\hline & & $\mathrm{N}$ & Mean Rank & Sum of Ranks \\
\hline Volume_Transportation_ & Negative Ranks & $19^{\mathrm{a}}$ & 15.68 & 298.00 \\
after - Volume__ & Positive Ranks & $13^{\mathrm{b}}$ & 17.69 & 230.00 \\
Transportation_before & Ties & $0^{\mathrm{C}}$ & & \\
& Total & 32 & & \\
\hline
\end{tabular}

a. Volume_Transportation_after < Volume_Transportation_before

b. Volume_Transportation_after > Volume_Transportation_before

c. Volume_Transportation_after $=$ Volume_Transportation_before

Sources : Data processed (2019)

Table 4.28 shows the Wilcoxon Ranks of transportation subsector data. The result, there were 19 companies decrease in trading volume and 13 companies increase in trading volume. Then the paired sample t-test can be tested.

Table 4.29

Wilcoxon Signed Rank Test (T-Test) for Transportation Subsector

\begin{tabular}{|l|r|}
\hline & $\begin{array}{r}\text { Volume_Transportation_- } \\
\text { after - Volume_ } \\
\text { Transportation_before }\end{array}$ \\
\hline Z & $-.636^{\mathrm{a}}$ \\
Asymp. Sig. (2-tailed) & .525 \\
\hline
\end{tabular}

a. Based on positive ranks.

b. Wilcoxon Signed Ranks Test

Sources : Data processed (2019)

Paired sample t-test of stock price for transportation subsector shows significance (sig) 0.525. Because the signifance of $0.525>0,05$, the interference taken is the stock price for transportation has no significant differences before and after the presidential election.

\section{Non Building Construction Subsector}

Kolmogrov-Smirnov test used the following rules :

1. If the significance $\leq 0.05$ then the data was abnormally distributed.

2. If the significance $>0.05$ then the data was normally distributed
Table 4.30

Non Building Construction Subsector Normality Test

\begin{tabular}{|c|c|c|c|}
\hline & & $\begin{array}{c}\text { Volume_Non } \\
\text { building } \\
\text { construction_ } \\
\text { before }\end{array}$ & $\begin{array}{l}\text { Volume_Non } \\
\text { building } \\
\text { construction_ } \\
\text { after }\end{array}$ \\
\hline $\mathrm{N}$ & & 8 & 8 \\
\hline \multirow{2}{*}{ Normal Parameters ${ }^{a, b}$} & Mean & 5481388.0063 & 4931749.0000 \\
\hline & Std. Deviation & 8140050.458 & 5098282.644 \\
\hline Most Extreme & Absolute & .358 & .190 \\
\hline \multirow[t]{2}{*}{ Differences } & Positive & .358 & .190 \\
\hline & Negative & -.250 & -.167 \\
\hline Kolmogorov-Smirnov Z & & 1.011 & .536 \\
\hline Asymp. Sig. (2-tailed) & & .258 & .936 \\
\hline
\end{tabular}

Sources : Data processed (2019)

Table 4.30 shows $\mathrm{Z}$-value of each trading volume as:

1. Z-value for trading volume variable before the Presidential Election is 1.011 with the signifance (sig) 0.258. Because the significance is $0.258>$ 0.05 , then the interference taken is the trading volume data before the Presidential Election was normally distributed.

2. Z-value for trading volume variable after the Presidential Election is 0.536 with the signifance (sig) 0.936. Because the significance is $0.936>$ 0.05 , then the interference taken is the trading volume data after the Presidential Election was normally distributed.

From the normality test, it can be concluded that the data on average trading volume before and after the presidential election were normally distributed. Therefore, it can be used to test the hypothesis by using paired sample t-test.

Table 4.31

Paired Sample T-Test of Trading Volume for Non Building Construction Subsector

\begin{tabular}{|c|c|c|c|}
\hline & & & $\begin{array}{c}\text { Pair 1 } \\
\text { Volume_Non building } \\
\text { construction_before - } \\
\text { Volume_Non building } \\
\text { construction_after }\end{array}$ \\
\hline \multirow{5}{*}{$\begin{array}{l}\text { Paired } \\
\text { Differences }\end{array}$} & \multicolumn{2}{|l|}{ Mean } & 549639.00625 \\
\hline & \multirow{2}{*}{\multicolumn{2}{|c|}{$\begin{array}{l}\text { Std. Deviation } \\
\text { Std. Error Mean }\end{array}$}} & 4018869.66661 \\
\hline & & & 1420884.99698 \\
\hline & 95\% Confidenccen & Lower & -2810220.11634 \\
\hline & $\begin{array}{l}\text { Internal Of the } \\
\text { Difference }\end{array}$ & Upper & 3909498.12884 \\
\hline $\mathrm{t}$ & & & .387 \\
\hline df & & & 7 \\
\hline Sig. (2-tailed) & & & .710 \\
\hline
\end{tabular}

Sources : Data processed (2019) 
Paired sample t-test of trading volume for nonbuilding construction subsectors shows t-value is 0.387 with significance (sig) 0.710. Because the signifance of $0.710>0.05$, the interference taken is the trading volume for non-building construction subsectors has no significant differences before and after the presidential election. Positive value $(+)$ on $t-$ value shows that the average trading volume before the presidential election year 2019 higher than the average trading volume after the presidential election.

Paired sample t-test of trading volume for each subsector shows no significant differences before and after the presidential election. From the result, the interference taken was accepted the alternative hypothesis - There is no a sigificant difference of trading volume before and after the Indonesia Presidential Election year 2019 within infrastructure sector listed on Indonesia Stock Exchangell. This can also be proven by a test conducted directly on the five sub-sectors, namely in 55 companies directly. The results of the test can be seen in table 4.31

Table 4.32

Paired Sample T-Test of Trading Volume for All Infrastructure Sectors

\begin{tabular}{|c|c|c|c|}
\hline & & & $\begin{array}{c}\text { Pair 1 } \\
\text { Volume_subsector_- } \\
\text { before - Volume_- } \\
\text { subsector_after }\end{array}$ \\
\hline \multirow{5}{*}{$\begin{array}{l}\text { Paired } \\
\text { Differences }\end{array}$} & & -12117107.95746 \\
\hline & \multicolumn{2}{|l|}{ Std. Deviation } & 90509902.08107 \\
\hline & & 12204352.70692 \\
\hline & 95\% Confidenccen & Lower & -36585361.92531 \\
\hline & $\begin{array}{l}\text { Internal Of the } \\
\text { Difference }\end{array}$ & Upper & 12351146.01039 \\
\hline $\mathrm{t}$ & & & -.993 \\
\hline df & & & 54 \\
\hline Sig. (2-tailed) & & & .325 \\
\hline
\end{tabular}

Sources : Data processed (2019)

Paired sample t-test of trading volume for all subsectors shows t-value is -0.993 with significance (sig) 0.325 . Because the signifance of $0,325>0,05$, the interference taken is the trading volume for all subsectors has no significant differences before and after the presidential election. Negative value (-) on tvalue shows that the average strading volume before the presidential election year 2019 lower than the average trading volume after the presidential election.

\section{$3^{\text {rd }}$ Hypothesis Discussion}

The third hypothesis in this study is - There is no a sigificant difference of stock price before and after the Indonesia Presidential Election year 2019 between infrastructure sector and other sectors listed on Indonesia Stock Exchangell. The hypothesis is tested by using one sample sample t-test.

Table 4.33

Stock Price of Infrastructure Sector Test

\begin{tabular}{|l|c|c|c|c|}
\hline & $\mathrm{N}$ & Mean & $\begin{array}{c}\text { Std. } \\
\text { Deviation }\end{array}$ & $\begin{array}{c}\text { Std. Error } \\
\text { Mean }\end{array}$ \\
\hline $\begin{array}{l}\text { Price_Infrastructur_ } \\
\text { Sector }\end{array}$ & 55 & -12.0896 & 255.21913 & 34.41374 \\
\hline
\end{tabular}

Sources : Data processed (2019)

Table 4.34

Stock Price of Other Sectors T-Test

\begin{tabular}{|c|c|c|c|}
\hline & & & $\begin{array}{c}\text { Price_Infrastructur_ } \\
\text { Sector }\end{array}$ \\
\hline \multirow{6}{*}{$\begin{array}{l}\text { Test Value } \\
=55.968\end{array}$} & \multicolumn{2}{|l|}{ t } & -1.978 \\
\hline & & 54 \\
\hline & \multicolumn{2}{|l|}{ Sig. (2-tailed) } & .053 \\
\hline & \multicolumn{2}{|l|}{ Mean Difference } & -68.05762 \\
\hline & \multirow{2}{*}{$\begin{array}{l}95 \% \text { Confidence Interval } \\
\text { of the Difference }\end{array}$} & Lower & -137.0530 \\
\hline & & Upper & .9378 \\
\hline
\end{tabular}

Sources : Data processed (2019)

Table 4.33 shows the average stock price in infrastructure sector is increased by 12.0896 . Negative value (-) on t-value shows that the average stock price before the presidential election year 2019 lower than the average stock price after the presidential election. In other hand, table 4.40 shows the average stock price in other sectors are decreased by 55.968 . Positive value (+) on $t$-value shows that the average stock price before the presidential election year 2019 higher than the average stock price after the presidential election. It means there is difference market reaction of stock price in infrastructure sector and other sectors. One sample t-test of stock price for other sectors shows t- value is 1.978 with significance (sig) 0.053 . Because the signifance of $0.053>0.05$, the interference taken is the stock price for all sectors has no significant differences before and after the presidential election. So then the interference taken is accepted the alternative hypothesis -There is no a significant difference of stock price before and after the Indonesia Presidential Election year 2019 between infrastructure sector and 
other sectors listed on Indonesia Stock Exchange.

\section{$4^{\text {th }}$ Hypothesis Discussion}

The fourth hypothesis in this study is - There is no a sigificant difference of trading volume before and after the Indonesia Presidential Election year 2019 between infrastructure sector and other sectors listed on Indonesia Stock Exchange. The hypothesis is tested by using one sample sample t-test.

\section{Table 4.35}

Trading Volume of Infrastructure Sectors Test

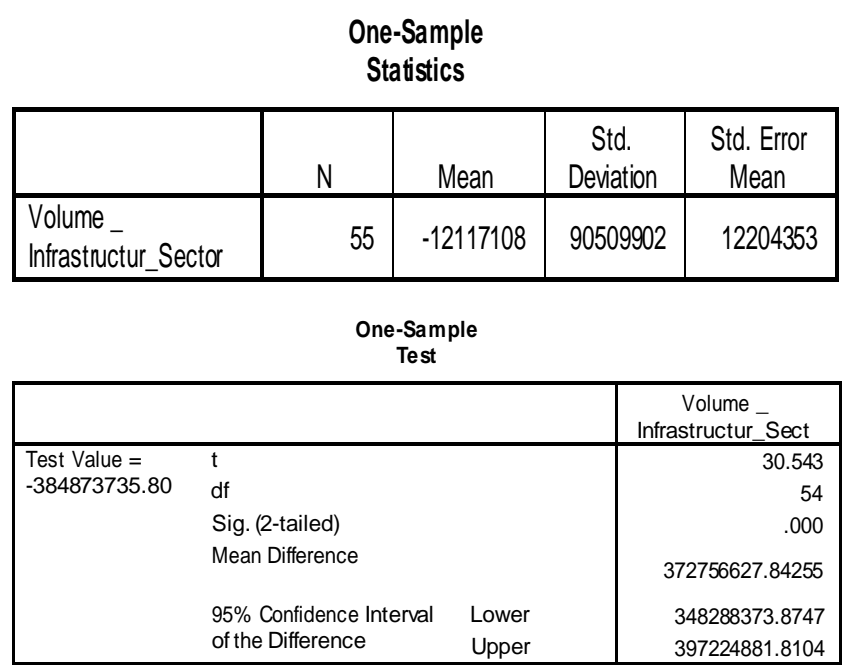

Sources : Data processed (2019)

Table 4.35, shows the average trading volume in infrastructure sector is increased by 12117108 . Poitive value $(+)$ on $t$-value shows that the average trading volume before the presidential election year 2019 higher than the average trading volume after the presidential election. In other hand, table 4.42 shows the average trading volume in other sectors are increased by 334873735.80 . It means there is a similar market reaction of trading volume in infrastructure sector and other sectors. One sample ttest of trading volume for other sectors shows t-value is 30.543 with significance (sig) 0.000 . Because the signifance value $0.00<0.05$, the interference taken was trading volume for all sectors has significant differences before and after the presidential election. From the result, the interference taken was rejected the alternative hypothesis - There is no a sigificant difference of trading volume before and after the Indonesia Presidential Election year 2019 between infrastructure sector and other sectors listed on Indonesia Stock Exchangell. In other words, there was significant differences of trading volume before and after presidential election year 2019.

\section{Conclusions, Limitations, and Suggestions Conclusions}

Based on the discussion in the previous chapters, this research was aimed to analyze the price and trading volume of stocks in the infrastructure sector listed on IDX before and after the presidential election 2019. The conclusions are as follow:

1. 1. Based on the statistical test of average stock price within infrastructure sector during the event period, it was found that there was no significant difference in the average stock price before and after the presidential election year 2019.

2. Based on the statistical test of average trading volume of stocks within infrastructure sectors during the event period, it was found that there was no significant difference in the average trading volume before and after the presidential election year 2019.

3. Based on the statistical test of average stock price between sectors during the event period, it was found that there was no significant difference in the average stock price before and after the presidential election year 2019

4. Based on the statistical test of average trading volume of stocks between sectors during the event period, it was found that there was significant difference in the average trading volume before and after the presidential election year 2019.

5. Generally, the results of this research there is no reaction in stock price, both between sectors and within infrastructure sector. While in the volume trading, there was reaction between sectors, but there was no reaction within infastructure sector. So, there were market reaction in Indonesia capital market during the event, but the reaction did not caused by political event. In other words, Indonesian capital market (in this case IDX) did not react to the presidential election.

\section{Limitations}

This study certainly has some limitations. 
There are several limitations in this study, such as:

1. This study doesn't used data model. The data only stock price and trading volume of stock. Meanwhile, there are calculation models that represent the stock price and trading volume.

2. This study only focus on a superior program of ongoing government, meanwhile the ongoing government not only take focus on the superior program.

3. This study cannot control other factors that influence stock price and trading volume during event period

\section{Suggestions}

The suggestions for next researches that can be used as references are:

1. Increase the number of programs in order to describe the real situation in capital market.

2. Upgrade the research by using calculation model as the variable, in order to see the consistency of this research results.

\section{References}

Chandra, T. (2015). Impacts of Indonesia's 2014 Presidential Election towards Stock Priceso Indonesia Stock Exchange. International Journal of Business and Management, 10(7). https://doi.org/10.5539/ijbm.v10n7p172.

Halim, Abdul and Nasuhi Hidayat. 2010. Studi Empiris tentang Pengaruh Volume Perdagangan dan Return Terhadap Bid-Ask Spread Saham Industri Rokok di BEJ dengan Model Korelasi Kesalahan, Jurnal Riset Akuntansi Indonesia. Vol, 3

Imelda, I., Siregar, H., \& Anggraeni, L. (2016). Abnormal Returns and Trading Volume in the Indonesian Stock Market in Relation to the Presidential Elections in 2004, 2009, and 2014. Bisnis \& Birokrasi Journal, 21(2). https://doi.org/10.20476/jbb.v21i2.4319.
Paper No.19812.

Kementerian Keuangan Republik Indonesia. (2018). Apbn 2019. Asumsi Dasar Ekonomi Makro APBN 2019, 5. Retrieved from https://www.kemenkeu.go.id/apbn2019.

Marcellyna, F., \& Hartini, T. (2011). Pengaruh Earning Per Share (Eps) Terhadap Harga Saham Lq45 Di Bursa Efek Indonesia (Bei). Jurnal Akuntansi STIE MDP, 1-7.

Morck, R., Shleifer, A., Vishny, R.. (1990), The Stock Market and Investment: Is the Sock Market a Sidesshow ?. Brookings Paper on Economic Activity, 2, 157-202.

Nurhaeni, Nunung. (2009). Dampak Pemilihan Umum Legislatif Indonesia Tahun 2009 Terhadap Abnormal Return dan Aktivitas Volume Perdagangan Saham di BEI (Uji Kasus pada Saham yang Terdaftar dalam Kelompok Perusahaan LQ 45). Thesis. Semarang: Universitas Diponegoro.

P, D. G. O. S., \& Sari, M. M. R. (2015). Reaksi Pasar Atas Peristiwa Pilpres 2014. E-Jurnal Akuntansi Universitas Udayana, 12(3), 465480 .

Rummel, professor and David A. Heenan (1978). How Multinational Analyze Political Risk. University of Hawaii

Sihotang, E. M., \& Mekel, P. A. (2015). Reaksi Pasar Modal terhadap Pemilihan Umum Presiden tanggal 9 Juli 2014 di Indonesia. Jurnal EMBA, 3(1), 951-960.

Schneider, F., Frey, B. (1985), Economic and political determinants of foreign direct investments. World Development, 13(2), 161-175.

Subagio, Ahmad, (2016). Marketing In Business, Edisi pertama, Jakarta: Mitra Wacana Media.

Vega-Gordillo, M., Alvarez-Arc, J.L. (2003), Economic Growth and freedom: A causality study. Cato Journal, 23(2). 